\title{
How Can a Teacher Become the Better Version of Oneself?
}

\author{
Özlem UTKU ${ }^{1}$
}

\begin{abstract}
In order to improve professionally, teachers need to question themselves throughout their teaching because one can get feedback from oneself as well instead of listening to others' comments, suggestions or questions. On the other hand, getting feedback from colleagues and learners is invaluable for professional improvement. This study was conducted as a self-study by a novice teacher. It was aimed at exploring the teaching practice of the teacher by focusing on the motivation issue specifically. Two critical friends actively participated in the study whereas the students of the teacher were passively involved in this self-study, too. The data were collected through weekly diaries, Teacher Sense of Efficacy Scale, Student Trust in Teacher Survey and written reflections of critical friends. Content analysis was utilized to analyses qualitative data and quantitative data were analyzed through SPSS, descriptive statistics were computed to reveal quantitative results. The findings showed that teacher self-efficacy is crucial to sustaining a productive teaching environment and a healthy teacher-student relationship. In addition, it was found out that teachers have various roles and responsibilities, which may sometimes overlap, both in and outside the classroom. Regarding the self-study methodology and critical friendship, it was concluded that conducting a self-study is extremely helpful for professional development of a teacher because evaluation and criticism allow teachers to question themselves in a critical manner and investigate what has been done and what could have been done for the betterment of their teaching and professional being.
\end{abstract}

Keywords: Self-study, self-efficacy, motivation, English language teacher

${ }^{1}$ Bayburt University, Bayburt Education Faculty, Department of Foreign Language Education, e-mail: ozlemutku36@gmail.com, ORCID: 0000-0001-7978-9195 
AJESI - Anadolu Journal of Educational Sciences International, 2019; 9(2): 852-880

DOI: 10.18039/ajesi.583809

\section{Introduction}

Elon Musk gave a very useful advice in a rather ordinary interview conducted by Lance Ulanoff in 2012. "I think it is very important to have a feedback loop, where you're constantly thinking about what you've done and how you could be doing it better. I think that's the single best piece of advice: constantly think about how you could be doing things better and questioning yourself," he stated.

Questioning yourself by considering your values, opinions and actions can be highly beneficial to both your personal and professional development as it is also emphasized by Elon Musk. However, when using this feedback loop, it is crucial to be fair and critical enough to create our better versions as individuals and professionals. We should not be so harsh that we cannot even realize good sides of what we are doing or should not be such an extreme optimist or so pollyannaish that we cannot see our deficiencies in an objective manner. Thus, we need to balance optimism and pessimism to use our feedback loops in an efficient and useful way. Conducting self-study research makes this feedback loop more apparent since it allows professionals to think over their viewpoints, performances and deeds critically. Besides questioning one's self as an individual, getting feedback from one's self about his or her practices can be very helpful in improving professionally. However, it should be noted that self-study is not only asking questions to yourself and reflecting upon your beliefs and practices, it is a collaborative inquiry process (Samaras, 2010).

Alan (2016, p.8) points out that self-study is now recognized and accepted as a prestigious research method. For this reason, recently several studies have been conducted by utilizing self-study methodology and it has been reported that in teacher education self-study research methodology enables teachers to inquire into and evaluate their practices (Akinbode, 2013; Aydın, 2016; Loughran, 2006; Schuck and Russell, 2005). Being suggested by a professor and reading studies concluding benefits of conducting a self-study, I decided to 
AJESI - Anadolu Journal of Educational Sciences International, 2019; 9(2): 852-880 DOI: 10.18039/ajesi.583809

conduct a self-study on motivation and self-efficacy since self-efficacy has a strong effect on teachers' job satisfaction and achievement (Caprara et al., 2006), students' motivation and achievement (Mojavezi \& Tamiz, 2012), teachers' burnout and classroom management skills (Brouwers \& Tomic, 2000) and use of instructional strategies (Y1lmaz, 2011).

As my students, enrolled in a young state university, mostly have problems about getting motivated, I especially wanted to focus on the motivation issue. Due to the city where they study and I work, they generally complain about the things they cannot do as university students. Their complaints also affect my motivation, our classroom environment and course of my course because I always spend the last minutes of my course soothing and remotivating them. Therefore, I wanted to inquire into my practices and my perceived self-efficacy regarding what I am doing to motivate my students, whether my approach is affecting their level of motivation positively and what I am doing to help my students value learning and teaching English.

\section{Theoretical Background}

\section{Self-study}

Pinnegar and Hamilton (2009, p. v) begin their book, which serves as the primary source of information and referenced by researchers when conducting self-study research, by stating that "self-study is a stance toward understanding the world." Additionally, it is emphasized by Pinnegar and Hamilton (2009, pp. v-vii) that self-study methodology does not reject other paradigms, strategies or methods in social sciences but instead self-study researchers use those methods in a very thorough and careful way by "considering the researchers' position as both the researcher and researched and as having a central role in the practice being studied." 
AJESI - Anadolu Journal of Educational Sciences International, 2019; 9(2): 852-880 DOI: 10.18039/ajesi.583809

It seems rather complicated to conduct self-study research or understand the cruxes of self-study with the explanations given above. To make it more clear, the Five Foci Framework presented in the book of Samaras (2010) is presented below. The Five Foci Framework helps us manage the self-study process better and more easily because it defines what a self-study is in a very clear way. According to the framework presented throughout Samaras's (2010) book, self- study research is:

- A personal situated inquiry,

- A critical collaborative inquiry,

- Improved learning,

- A transparent and systematic research process, and

- Knowledge generation and presentation.

The second item puts emphasis on the fact that self-study research is "critical collaborative inquiry", so we do not conduct a self-study by ourselves at all. Instead, we collaborate with others while carrying on our self-study research. The critical friend is the term used to define the person with whom you collaborate during your self-study research. More precisely, according to Samaras (2010, p. 5) "critical friends are trusted colleagues who seek support and validation of their research to gain new perspectives in understanding and reframing of their interpretations." Considering the Five Foci Framework and definition of a critical friend, self-study research can be explained as a research methodology in which researchers inquire into their personal opinions and practices with the contributions and help of critical friends to improve themselves.

As it is suggested in Aydin's (2016) study, conducting a self-study enables teachers and teacher trainers to enhance their self-awareness, and accordingly contributes to their professional development in a positive manner. Similarly, Schuck and Russell (2005, pp. 117118) note that being critical friends of each other, they developed new perspectives regarding 
AJESI - Anadolu Journal of Educational Sciences International, 2019; 9(2): 852-880 DOI: 10.18039/ajesi.583809

their contexts and new insights into their purposes and challenges, so it can be concluded that self-study methodology allows teachers to assess themselves in a critical manner and provides new aspects in terms of their professional attributes. Since teacher self-efficacy is one of the attributes that contribute to the professional identity of a teacher, investigating self-efficacy through self-study can provide useful outcomes due to self-study methodology's offering critical self-evaluation for teachers' professional development (Aydın, 2016, p. 975).

\section{Motivation}

Does someone study hard and pass an exam to please his/her parents, teachers or himself/herself? Can rewards affect how much motivated a learner is? On the other hand, to what extent can teachers influence students' level of motivation? Firstly, the term motivation should be clarified to answer these questions and to facilitate our understanding of what being motivated means. According to Ryan and Deci (2000, p. 54), "to be motivated means to be moved to do something". More precisely, if someone has a reason, enthusiasm or eagerness to behave, act or perform in a particular way, this person can be described as a motivated person. Whether there are extrinsic reasons that have someone do something or the person is intrinsically motivated to do something is closely related to the types of motivation. Taking into account the reasons that motivate people to carry out something, basically intrinsic and extrinsic reasons are emphasized in Self-Determination Theory of Deci and Ryan (1985) as well as in the relevant literature (Covington, 2000, p. 22). Rewards, praises, reinforcement, and other kinds of motives which have an external origin or base are the examples of extrinsic reasons. People are motivated because of such external factors, and this type of motivation is defined as extrinsic motivation. When individuals are extrinsically motivated, they perform certain tasks to get good comments or feedback from others, to please others or to receive rewards and praises. 
AJESI - Anadolu Journal of Educational Sciences International, 2019; 9(2): 852-880 DOI: 10.18039/ajesi.583809

Even though motivation is divided into two basic types of motivation, individuals may have both extrinsic and intrinsic reasons to do something at the same time - that is to say, both extrinsic and intrinsic motivation can lead someone to perform something since they are closely related to each other. However, unlike extrinsic motivation, intrinsic motivation is related to individuals' inner motives and external factors do not have an influence on being motivated. Considering the educational context, it can be said that extrinsic motivation is boosted due to the assignments, examinations, quizzes, and the competitive environment where getting good grades is crucial. However, once learners have developed intrinsic motivation, they will be more autonomous and independent learners, and so they will have unique reasons to do something. Therefore, teachers should guide learners to develop and sustain intrinsic motivation as well as they should make use of extrinsic reasons in order to keep learners alert.

\section{Perceived self-efficacy}

Bandura (1994) defines perceived self-efficacy as "people's beliefs about their capabilities to produce determined levels of performance", and he points out that people's self-efficacy beliefs affect how they behave, think, feel, and how they motivate themselves. Thus, it can be stated that if people feel a strong sense of self-efficacy, they will not approach difficult tasks as threats that they should avoid dealing with, but they will think that they are tasks to be managed and mastered. Specifically, teacher self-efficacy is related to "teachers' behaviour in the classroom, their efforts they put into their teaching, the goals they set and their level of aspiration" (Tschannen-Moran et al., 1998, pp. 222 - 223). Teacher's beliefs about his/her capability to plan, conduct and organize actions that are necessary to successfully fulfil a specific teaching task in a specific teaching context explain the term "teacher efficacy". If teachers question themselves about their self-efficacy, they will be able 
AJESI - Anadolu Journal of Educational Sciences International, 2019; 9(2): 852-880 DOI: 10.18039/ajesi.583809

to explore their practices in a more efficient way. In addition, when they think critically over their efforts, behaviours and actions, they can be more conscious of their self-efficacy, which will help them to discover their strengths and weaknesses.

Approaching the concept of efficacy from a collectivist point of view, Donohoo, Hattie and Eells (2018, p. 43) also focus attention on the importance of understanding efficacy, and further points out that "success lies in the critical nature of collaboration and the strength of believing that administrators, faculty, and learners are able to accomplish great things all together." Therefore, teachers should consider incorporating other stakeholders in education into the process of exploring their self-efficacy. On the other hand, associating teacher self-efficacy to collective efficacy, Ninković and Knežević Florić (2018) investigated the relationships among transformational school leadership, teacher self-efficacy and perceived collective teacher efficacy in their research study. It was concluded from their findings that "collective teacher efficacy is strongly related to teachers' perceived selfefficacy beliefs" (Ninković \& Knežević Florić, 2018, p. 60). In the light of Ninković and Knežević Florić's (2018) study, it can be suggested that the more teachers believe in their professional competence and teaching skills, the more efficiently they contribute to collective efficacy.

A very recent research study, grounded in English teachers' self-efficacy beliefs, Thompson and Woodman's (2019) study aims at investigating Japanese high school English language teachers' foreign language teaching efficacy beliefs. Through a scale designed by the researchers considering the Japanese context, the dimensions of dormant teacher efficacy beliefs were explored. The findings revealed collaborative and individual dimensions as well as certain context-specific aspects of teacher efficacy. Additionally, it was found that "some dimensions of foreign language teaching efficacy can be generalized to broader fields as well" and "being competent to use L2" was determined as one of these dimensions (Thompson \& 
AJESI - Anadolu Journal of Educational Sciences International, 2019; 9(2): 852-880 DOI: 10.18039/ajesi.583809

Woodman, 2019, p. 48). The aforementioned studies collectively suggest that encouraging teachers to explore their self-efficacy beliefs provides them with opportunities for the betterment of their teaching skills and professional competence. Hence, the research studies based on teacher efficacy might be highly useful for teachers to discover the notion of selfefficacy and improve their teaching abilities in the light of suggestions drawn as a result of such studies.

\section{Significance of the study}

There are numerous studies conducted with novice teachers and investigating their self-efficacy beliefs (Chester \& Beaudin, 1996; İpek et al., 2018; Onafowora, 2005; Ozder, 2011; Tschannen-Moran \& Hoy, 2007). However, the number of self-study researches conducted by novice teachers or teacher trainers themselves is not enough to explore what novice teachers experience from their points of view. Furthermore, despite the number of studies on the relation between motivation and education (Ames, 1992; Kiziltepe, 2000; König, 2006; Nicholls, 1979; Papastergiou, 2009), there are not many research studies investigating student motivation from the perspectives of both teacher and learners. Moreover, although the studies given above focus on self-efficacy and motivation, there are not nearly any research studies predicated on student motivation and teacher self-efficacy together.

This self-study aims to examine a novice teacher's perceived self-efficacy beliefs regarding her teaching practice and specifically the way she motivates her students. It is also aimed at investigating whether the teacher's perceptions overlap his/her students' opinions on her teaching practice, actions and self-efficacy. 
AJESI - Anadolu Journal of Educational Sciences International, 2019; 9(2): 852-880

DOI: 10.18039/ajesi.583809

\section{Methodology}

\section{Research Design}

In fact, I wanted to conduct my self-study research on error analysis because I carried out the writing course this year and I was questioning myself about whether I was giving enough feedback to my students and how I was giving feedback or how my comments and/or feedback were perceived by my students. However, while I was asking questions to myself in order to generate my research questions, I realized that all the answers to my questions were, in fact, closely related to self-efficacy. I am a novice teacher and I am trying to find the best version of myself. I believe that conducting a self-study on self-efficacy when I am novice can be a good guide for my professional development and future career thanks to the insights I will gain at the end of this study. In addition to this, I can also improve my current practices conducting a self-study and be a good model for my students as well.

During this process that is a relatively new experience for me, I openly asked questions about my teaching practice, put what I planned and thought into practice, evaluated my practices and examined the effects of my efforts on my students, as it is also suggested by Samaras (2010, p. 5). My critical friends contributed a lot to this process. Thanks to their comments and questions, I could open my mind to new ideas, find different ways of doing the same thing, and experience a more fruitful questioning process.

\section{Critical Friends}

In this self-study, actually, I had 32 critical friends in total. First two critical friends of mine, Xiu and Uraz (pseudonyms) are my classmates who are also taking their master's degrees in ELT, and they were always with me during this process. Uraz is a male working as an instructor at a state university in Turkey, and Xiu is a Chinese female, an Erasmus student 
AJESI - Anadolu Journal of Educational Sciences International, 2019; 9(2): 852-880 DOI: 10.18039/ajesi.583809

in Turkey. I was very lucky to have two critical friends from two different contexts because both of them could assess my teaching practices from different points of view. Uraz works at a different university and teaches English to students from several different departments, so his students have different purposes of learning English when compared to mine, yet he has stated that he also experiences motivation-related problems, so he was highly familiar to my problems and questions. Thus, he asked very practical questions and made realistic comments on my practices. Moreover, as he is more experienced than me in teaching English, his contributions, questions and comments were of vital importance in probing into my practice. On the other hand, Xiu comes from a totally different educational context and has experienced studying at a Turkish university for only 4 or 5 months. Even though I and Uraz introduced the Turkish education system to her and told how, where and to whom we teach English, she is a complete foreigner and I believe that being listened by a complete foreigner can be highly advantageous in this inquiry-based process because she grew up and received education in a different country, and for this reason, she considered my teaching practices from a different angle. Additionally, I was able to understand and evaluate how I was teaching and what I was doing in practice better and more critically throughout this inquiry-based process thanks to having a foreign critical friend who is not familiar to the education system in Turkey.

Besides Uraz and Xiu, my students were critical friends of mine. My students are preparatory class students enrolled in the Department of English Language Teaching, so they can be regarded as novice pre-service English language teachers. They, in fact, did not act as real critical friends during the study because getting their feedback weekly could be a difficult task for both me and my students. The syllabus was relatively loaded and my student could get bored very easily, so following the same procedure as I did with my Urax and Xiu might not work efficiently with my students. Therefore, I decided to ask for their opinions in the end, rather than wanting them to keep a journal weekly as my critical friends did. 
AJESI - Anadolu Journal of Educational Sciences International, 2019; 9(2): 852-880 DOI: 10.18039/ajesi.583809

They shared their opinions and perceptions about my abilities and teaching practices as a teacher in terms of fostering their motivation and involvement in my course. Fortunately, my students were the participants in the present study because they are the ones who are affected by my teaching practices and listening to them in terms of how my practices are perceived by them can be extremely useful for enquiring into what and how I am teaching in practice.

\section{Data Collection Instruments}

Making decisions on the data collection instruments is the most challenging step of my self-study research. However, after making my mind clear and focusing on my aims and questions, the decision process became relatively easy. To collect data, I utilized three instruments: weekly diaries, Teacher Sense of Efficacy Scale (TSES) developed by Tschannen-Moran and Woolfolk Hoy (2001), and Student Trust in Teachers Scale developed by Adams and Forsyth (2009). Additionally, I said to my students that besides answering the questions of the scale, they could write their reflections about my teaching practices, my relationship with them, and the way I motivated them.

\section{Weekly diaries}

I kept weekly reflective diaries and when writing my diaries, I sought the answers for the following questions:

- How much can I do to motivate students who are less interested in my course and learning English?

- How much can I get my students to believe that they can be proficient users of English? 
AJESI - Anadolu Journal of Educational Sciences International, 2019; 9(2): 852-880 DOI: 10.18039/ajesi.583809

- What do I do to help my students value learning and teaching English?

After writing my diaries weekly, I sent them to my critical friends to get their comments and questions. As my course was conducted on Thursdays, we chose Sundays as the day when I would send them my diaries. By doing so, I had enough time to reflect upon my practice, write my diary, and send them on time. I wrote my reflective diaries, and my critical friends sent their comments and questions for 6 weeks. Because I got their reflective feedback on my practices before Thursday, I had the chance of reflecting on their questions and comments and planning my course accordingly.

\section{Teacher sense of efficacy scale}

Teacher Sense of Efficacy Scale was developed by Tschannen-Moran and Woolfolk Hoy (2001) with the aim of enabling teachers to assess their capability concerning instructional strategies, student engagement, and classroom management. There are two versions of the scale: the long form includes 24 items and the short form consists of 12 items. I utilized the long form but I did not give a response to all the questions because the scale is a Likert-type scale consisting of nine responses, ranging from (1) 'None at all' to (9) 'A Great Deal'. Moreover, answering the questions as a whole without giving detailed responses may not reveal the ambiguous points clearly and cannot provide in-depth insights into my perceived self-efficacy. Therefore, alternatively, I answered the most relevant items to my teaching context and my problem as if they were open-ended questions.

\section{Survey of student trust in teachers}

As I have mentioned before, in addition to my critical friends' and my reflections on my self-efficacy, teaching practice and my relationship with my students regarding how I 
AJESI - Anadolu Journal of Educational Sciences International, 2019; 9(2): 852-880

DOI: 10.18039/ajesi.583809

motivate them, I wanted to examine my students' opinions about me as the teacher. With this in mind, I administered the Student Trust in Teachers Survey, and also I encouraged them to write their reflections upon me and my practices.

\section{Data Analysis}

I analysed the data through content analysis and utilizing the Statistical Package for Social Sciences 24.0 because data were collected both qualitatively and quantitatively. Upon analysing the data, I took three crucial points into account: my own reflections about my selfefficacy - how I perceive my self-efficacy as a teacher, my critical friends' comments and questions about my self-efficacy and teaching practice - whether I change or modify my practices after getting their feedback, and lastly my students' reflections about my selfefficacy and teaching practices - whether the way I assess and perceive myself overlap what they think about my self-efficacy and teaching practices.

\section{Findings and Discussion}

In the current self-study, the findings were presented and discussed in three subheadings. Firstly, the findings my weekly diaries provided were indicated and discussed respectively. Then, what my critical friends' comments and questions contributed to me was displayed, and lastly, comparison of my reflections and my students' reflections about me as a teacher, my teaching practices, and what I have done to motivate them was indicated by presenting statistical analysis as well. 
AJESI - Anadolu Journal of Educational Sciences International, 2019; 9(2): 852-880

DOI: 10.18039/ajesi.583809

\section{Analysis of My Weekly Diaries}

While analysing weekly diaries, roles and responsibilities of a teacher were taken into account. According to Machin et al. (2015, p. 31), one of the main roles of a teacher is to motivate learners so as to help and encourage them to develop their abilities and explore their aspirations. Moreover, it is suggested that what a teacher should do is not only to teach certain subject matters or prepare learners for assessment, but teachers should inspire learners "to change and develop their personal, social and professional skills to the best of their ability" (Machin et al., 2015, p. 31). Accordingly, by considering what the literature suggests regarding teachers' roles and responsibilities, eight main themes were found. Table 1 displays both the themes and their frequencies.

Table 1

The Themes Found in the Analysis of the Weekly Diaries and Their Frequencies

\begin{tabular}{lc}
\hline Theme & $\boldsymbol{f}$ \\
\hline 1. Promoting intrinsic motivation of my learners & 12 \\
\hline 2. Ensuring a supportive and safe communication environment & 10 \\
\hline 3. Planning learning activities considering the needs and interests of my learners & 8 \\
\hline 4. Providing my learners with feedback and appropriate points of referral when necessary & 10 \\
\hline 5. Assuring my learners of my full trust in them & 6 \\
\hline 6. Being organised & 8 \\
\hline 7. Being a model for my learners to inspire them & 8 \\
\hline 8. Facilitating my learners' involvement in the course & 12 \\
\hline
\end{tabular}

After the analysis of my weekly diaries, I first realized how much effort I put into increasing my students' motivation, and how much I cared about developing a good communication environment for a healthy teacher-student relationship. Moreover, findings emphasized that I attached great importance to my students' feelings, that is, whether they feel comfortable in my class, and they are happy being in the ELT Department or living in the 
AJESI - Anadolu Journal of Educational Sciences International, 2019; 9(2): 852-880 DOI: 10.18039/ajesi.583809

city where they study. The following extract indicates what I do to have my students understand that I understand them as well:

Since they looked anxious and tired of waiting for the exam, I suggested them waiting at my office. They kept asking questions about the results of the exams and final examinations. To change the topic, I asked how they spent their spare time. They said, 'We cannot do anything because there is nothing to do in this city.' They also complained about classmate relationships. I have understood that they want to spend time altogether but what they expect is not what happens in reality. I told them that they were all different and what they experienced was so normal.

To help them overcome their personal problems they encountered in their daily lives or in their relationships with their friends, I gave examples from my own life. I did so since I also wanted to be a model for my students to inspire them. In terms of the age and educational background, there is not a big difference between me and my students - that is to say, we went through the same process while getting prepared for the university entrance exam, we took the same exams, and thanks to my age, we listened to the same songs and watched relatively the same TV programs since we grew up within the same generation. Thus, because we have certain shared problems, interests and background, and we are nearly the same age, I do not have difficulty in thinking like them, so thanks to being young enough to understand the way they think and feel, my students are convinced that I truly understand them. The following diary entry demonstrates what I did for being a model for my students:

I talked about my experiences and they also shared their high school experiences with me. Lastly, we agreed on the fact that their relationships can be better in the following years so the only thing they need is time.

In addition, apart from serving as a model for my students, I also wanted to suggest intrinsic reasons to help my students get motivated without my guidance because I cannot 
AJESI - Anadolu Journal of Educational Sciences International, 2019; 9(2): 852-880 DOI: 10.18039/ajesi.583809

always be with them to encourage or motivate them when they feel tired, bored or depressed. To achieve this, firstly I excluded extrinsic reasons and then reminded them of their long-term goals. How I helped them remember their long-term goals to increase their intrinsic motivation is displayed in my following diary entry:

How did I respond? In fact, I both suggested them certain ways by reminding what we have done in our lessons and tried to remind them of the fact that they will be teachers of English very soon.

Regarding excluding extrinsic motives, I planned a learning activity in which my students would be active in preparing their own activities and reviewing certain topics. While deciding on the topics that would be covered by them, I considered the needs of my students. The following extracts display my decision-making process, and how I excluded extrinsic motives to make intrinsic motives recognizable for my students:

There are certain topics that my students have difficulties in comprehending, e.g. subject-verb agreement, passive voice and transitions. These topics have already been discussed within both grammar course and my course. Nevertheless, they make mistakes when using them while writing. Thanks to the weekly assignments, I can easily realize such mistakes. That's why I want to focus on these topics specifically.

To be honest, I wondered how my students would react if I wanted them to do something without getting pluses or earning points, so in short, my students are supposed to do something but they will not earn any plusses or points for the following three weeks (according to my plan).

I told them that they would not earn any points but they, fortunately, got very excited when I first shared my idea with them.

I think that letting my students choose how to learn by preparing their own learning activities was a very profitable experience for both them and me. Thanks to such an 
AJESI - Anadolu Journal of Educational Sciences International, 2019; 9(2): 852-880 DOI: 10.18039/ajesi.583809

experience guided by my students themselves, my students could understand that they have that creativity or instinct to teach English. Additionally, although I know that it is too early to want them to teach something, I think experiencing the happiness or satisfaction of helping others learn something can be useful for them to increase their intrinsic motivation. Additionally, I could see what kind of activities they enjoy doing while learning such topics, and this experience is very valuable feedback for me as well because after learning what kind of activities my students prefer, I can pay attention to their interests better while preparing my own additional teaching materials.

Besides motivation, I strongly believe that trust is also highly crucial in achieving a goal - that is to say, learners should believe in themselves to achieve their goals and teachers should also assure their trust in the students. If teachers seem unconvinced of their students' success, the students will also be unsure of whether or not they will be successful. For this reason, I assure my learners of my full trust in them, which is demonstrated in the following diary entry:

I answered their questions without giving 'big' clues about the exam. Moreover, more importantly, I told, 'I believe in you.'

Analysis of my diary entries has revealed that I have various roles and responsibilities as a teacher. Since I am a novice teacher, I am still trying to find who I am as a teacher, and conducting self-study research on self-efficacy without completing my second year as a teacher was an extremely valuable experience for me. I tried to discover my beliefs, explore how I respond to my students' problems or questions and what I do to sustain an encouraging, motivating, safe and supportive communication and classroom environment, and also what kind of activities, methods or strategies I use while teaching. 
AJESI - Anadolu Journal of Educational Sciences International, 2019; 9(2): 852-880

DOI: 10.18039/ajesi.583809

\section{Analysis of My Critical Friends' Comments and Questions}

As I have mentioned previously, having two active critical friends from two different contexts was highly advantageous for me. Thanks to the questions they addressed to me, I got motivated and encouraged to keep doing what I was doing and to act or behave in the same way without changing my manner. Furthermore, I was able to consider unclear points better. More precisely, I had difficulty in giving feedback to my students' assignments, that is, as they had weekly assignments weekly, reading them every week and giving feedback to each of them was a very challenging duty for me. Uraz suggested to me directing my students' attention to peer feedback:

Secondly, what do you think of directing them to give and take peer feedback? Do you think it can both reduce your workload and improve the sense of cooperation among the learners?

Besides, they clarified my mind by directing my attention to the activities to be used while teaching. Xiu's comment had me consider that I should have been aware of my students' problems they encounter in my course:

I also feel like you can ask or encourage them to write about their personal experiences, various emotions or problems in English writing. It may drive them to devote more to the writing and want more feedback from you because naturally, everyone longs for expressing themselves and being heard by others.

Both Uraz's and Xiu's questions about the responsibilities of my students drew my attention to the new activity I was planning to introduce, and after taking their comments and questions into account, I decided to modify the activity by decreasing their workload and by providing more guidance in the preparation process. The following extracts demonstrate questions of Uraz and Xiu respectively:

However, do you think some may feel overwhelmed because of the difficulties while teaching given the fact that they are first graders and do not know much about how to teach despite 
AJESI - Anadolu Journal of Educational Sciences International, 2019; 9(2): 852-880 DOI: 10.18039/ajesi.583809

you will help them with lesson planning and preparation of the materials? As you know the things in the classroom do not always go the way we plan before the lesson. Sometimes, we need to make some interactive decisions. What do you think you can do to prevent such a situation or overcome if it occurs?

Do you think it will be too difficult or overwhelming for some students to teach the most problematic grammar points since they even have trouble using them properly? If I were you, I would probably group the students more carefully, like assuring some intellectual students and underachievers in each group. In such way, the underachievers can feel less anxious about the assignment with the help of the intellectual ones and everyone can enjoy the task more and get more sense of achievement.

During this process, working with two critical friends enabled me to explore my strengths and weaknesses. I could not be brave enough to criticize and question myself or try new things or activities without their contributions. As it is also emphasized by Samaras (2010, p. 5), 'although we might have many troubles while trying to change the education system, we should know that the one thing we can try to improve and change is ourselves. And yet, support and constructive critique are necessary for that change.'

\section{Comparison of My Reflections and My Students' Feedback}

In my self-study, fortunately, I had 32 critical friends: Xiu, Uraz and my students. Literature suggests that critical friends are 'trusted colleagues' (Alan, 2016, p. 12; Samaras, 2010, p. 5). However, in this self-study, learners were also involved in the questioning process. I wanted to receive my students' feedback, listen to their questions and comments with the aim of becoming a better version of myself as a teacher because the ultimate aim of this self-study was to make me better and more qualified by enabling me to explore my strengths and weaknesses as a teacher. To discover the opinions of my students, a scale 
AJESI - Anadolu Journal of Educational Sciences International, 2019; 9(2): 852-880 DOI: 10.18039/ajesi.583809

questioning student trust in teachers (Adams \& Forsyth, 2009) was utilized. The scale was originally developed to examine student trust in all the teachers at their schools but I administered this scale to discover my students' trust in only me. For this reason, before the administration, I told my students that they were supposed to give a response to the items considering only me, not my colleagues. There were 10 items in the scale, and the students were to choose how much they agreed or disagreed with each statement by choosing one of five responses, ranging from (1) Strongly disagree to (5) Strongly agree. However, besides the scale, I wanted my students to write their opinions at the end of our last course. They did not have to write unless they wanted to do, I said that it was not compulsory to share their opinions. However, nearly all of them wrote what they thought about me, my teaching and my course.

Because both qualitative and quantitative data were collected to investigate my students' comments and questions, the findings were presented in a table and by demonstrating extracts. As Table 2 displays, the total score is 91,2 out of 100 , and I am highly pleased with what quantitative data revealed. It can be concluded that my students trust in me and understand my efforts I make to develop a good relationship with them, to teach them better and more effectively, and to motivate them in a more intrinsic manner.

Table 2

Analysis of Student Trust in Teachers Survey

\begin{tabular}{lc}
\hline Item & M \\
\hline Teachers are always ready to help. & 9,5 \\
\hline Teachers are easy to talk to at this school. & 9,4 \\
\hline Students learn a lot from teachers in this school. & 9,4 \\
\hline Students at this school can depend on teachers for help. & 8,5 \\
\hline Teachers at this school do a terrific job. & 8,6 \\
\hline Teachers at this school really listen to students. & 9,4 \\
\hline Teachers always do what they are supposed to do. & 8,9 \\
\hline Students are well cared for at this school. & 8,7 \\
\hline Teachers at this school are good at teaching. & 9,8 \\
\hline Teachers at this school are always honest with me. & 8,9 \\
\hline Total Score & 91,2 \\
\hline
\end{tabular}


AJESI - Anadolu Journal of Educational Sciences International, 2019; 9(2): 852-880 DOI: 10.18039/ajesi.583809

The highest score is given for my teaching, which is a very encouraging and motivating result for me because this was the first time I had given the writing course, and I had many questions and unclear points in my mind before the year started. Although I got prepared meticulously, read a lot of articles and blogs, searched books and various websites for activities, exercises, techniques and methods to be used throughout the year, decided on the course book after examining at least 5 books, prepared a very clear and comprehensible syllabus and I believed in and was sure of myself, I was still thinking whether or not my students would like the course, the way I would teach, the materials I would use and if I could say in the end that I was able to teach what I had planned in the beginning. Thus, seeing that my students think that I am good at teaching made me extremely happy and motivated. In addition to the survey's finding, it is also clarified in qualitative data as the following extracts demonstrate:

I think that your courses have contributed me a lot. My writing skills have improved thanks to you. (S3)

In my opinion, you are an expert in your field. (S4)

The teacher is highly qualified to lead the course. (S10)

I think that I got a good education from a well-educated teacher. The way she teaches, the additional activities and assignments are opportunities for me to learn something new and also sources of motivation. (S21)

Regarding my self-efficacy to motivate them and to establish a good relationship with them, as the results of the survey suggest, my students generally think that I am capable of motivating them, and building a healthy relationship with them. However, surprisingly and unfortunately, some of my students stated that in the beginning, they thought that I did not like them or treat everyone in the same way, but they changed their minds after they realized 
AJESI - Anadolu Journal of Educational Sciences International, 2019; 9(2): 852-880 DOI: 10.18039/ajesi.583809

that I treat every student equally without favouritism or discrimination. The following extracts demonstrate this:

To be honest, at the beginning of the term I was thinking that you did not like me at all. However, in time I understood that I was mistaken about you. I have understood that you are very sincere and more than a teacher, and you behave as if you were a friend of ours. (S19) First of all, in the first term, I was thinking that you did not treat all of us equally. When two students asked the same question, you gave a positive answer to one whereas you give a negative answer to the other one. However, this term I changed my mind and understood that you are more moderate and behave more equally. (P23)

Receiving such honest feedback is invaluable for me since I was not aware of the fact that some students thought that I was not fair. Actually, the reason why they thought so can be explained by my efforts I made to motivate the students who are more anxious about speaking in the class or basically making mistakes, so I might tell praise words to those with a high level of anxiety more frequently than I did to the ones with high self-esteem. However, as it can be seen clearly, I can be misunderstood by some of the students if I behave in this way. For this reason, I should find fairer ways to motivate my more anxious students.

Finally, I want to bring attention to the theme of 'being a model for my learners to inspire them'. The analysis of my diary entries revealed that one of my roles and responsibilities as a teacher is to be a model for my students, yet in the Student Trust in Teacher Survey, there is not an item questioning if I am a good model for them or not. Nonetheless, 4 students stated that I am an idol for them. To illustrate this, the following extracts can be displayed:

You are a perfect teacher and a perfect person with all your actions, your ambition to work and sweetness. You are also my idol. (S2)

I truly want to be a teacher like you in due course. (S4) 
AJESI - Anadolu Journal of Educational Sciences International, 2019; 9(2): 852-880 DOI: 10.18039/ajesi.583809

I hope I can be a teacher like you in the future. You are my idol. (S11)

Thanks to the teacher's humanitarian and solution-oriented personality, she is liked by her students and they model themselves on her. (S16)

When my own reflections and my students' reflections on me, my self-efficacy and my teaching are compared, it can be concluded that despite certain weaknesses of mine proposed by my students, my students' comments, and findings of the survey are encouraging for me to affirm and sustain my motivation and love of teaching.

\section{Conclusion}

This study was conducted as a self-study on self-efficacy. Three data collection instruments (weekly diaries, Teacher Sense of Efficacy Scale and Student Trust in Teachers Survey) were utilized as the data collection instruments. Except for the survey, data were collected qualitatively and were analysed through content analysis. The following conclusions can be proposed in light of the current study's results:

- Teacher's self-efficacy is highly crucial in sustaining a healthy teacher-student relationship as well as productive and purposeful teaching and learning environment. If the teacher has strong self-efficacy, he or she will propose better and more appropriate methods and activities while teaching and will be able to become an effective communicator as well. On the other hand, even if the teacher feels unconfident and has low self-efficacy regarding a subject matter or a course given in the beginning, he or she can develop his or her self-efficacy once enough preparation has been made beforehand and learners' needs, interests, weaknesses and strengths have been well-recognized.

- A teacher has various roles and responsibilities both in and outside the classroom environment, ranging from assuring the learners of my full trust in them to 
ensuring a supportive and safe communication environment. This conclusion is also consistent with that of Aydın's (2016) study.

- Critical friendship provides extremely useful insights into a teacher's professional identity. Teachers can carry out self-studies to keep themselves up-to-date and to discover what they are doing and whether or not they could have done it in a better or more efficient way. By evaluating and criticizing themselves, they will be able to investigate their approaches in a critical manner and will become more open to change, and being criticized by others will be relatively easy.

- While conducting a self-study when a teacher is a novice is invaluable for his or her professional development, utilizing self-study methodology after gaining experience will be relatively helpful for professional betterment because it can be difficult for an experienced teacher to realize what to do or if there is a need for change. However, working with colleagues will help experienced teachers evaluate themselves and discover the strengths and weaknesses in a critical and innovative way.

- Getting learners' opinions and feedback is a very useful way of evaluating yourself as a teacher. However, the appropriate manner should be adopted while asking learners for their feedback because they can misunderstand why the teacher wants them to share their opinions regarding his or her teaching and approach, and they can be harsh and unfair critics or may not share their real thoughts.

\section{Implications and Suggestions for Further Research}

Considering the conclusions proposed as a result of the current study, it can be noted that self-study methodology enables teachers, regardless of age or experience, to use their feedback loops effectively, together with critical friends. Furthermore, carrying out a self- 
AJESI - Anadolu Journal of Educational Sciences International, 2019; 9(2): 852-880 DOI: 10.18039/ajesi.583809

study on self-efficacy is extremely useful for a teacher since an evaluation process is activated and teachers can criticize themselves better and discover what has not been examined or thought over yet. On the other hand, if teachers want their students to be enthusiastic about the courses, they should pay attention to the way they motivate their students. When teachers try to put themselves in learners' shoes and to evaluate what they do in a critical manner, a more productive teaching environment can be sustained.

Therefore, it can be suggested that both experienced and novice teachers as well as teacher educators should carry out self-studies to explore their perceptions and to examine their deeds. In addition, to work collaboratively with their colleagues can be highly useful for their professional betterment because once they have discovered the benefits of questioning themselves with the help of others, they will be able to become more efficient professionals and their actual practices will possibly be more fruitful.

\section{Limitations}

During this self-study, the researcher's aim was to receive critical feedback from herself and her critical friends. She thought about what she did, and how she could have done it better. By its nature, although the researcher criticized herself as well, this self-study is not described as completely objective research. However, this fact is what literature suggests when conducting a self-study. To overcome the objectivity problem, one thing that can be suggested is to analyse the data after collecting it and repeating what was done afterwards (Aydin, 2016, p. 975).

\section{References}

Adams, C. M., \& Forsyth, P. B. (2009). Conceptualizing and validating a measure of student trust. Studies in School Improvement, 263-277. 
AJESI - Anadolu Journal of Educational Sciences International, 2019; 9(2): 852-880

DOI: 10.18039/ajesi.583809

Akinbode, A. (2013). Teaching as lived experience: The value of exploring the hidden and emotional side of teaching through reflective narratives. Studying Teacher Education, 9(1), 62-73.

Alan, B. (2015). Self-study as a qualitative research methodology in teacher education. Journal of Qualitative Research in Education - JOQRE, 4(1), 7-25.

Altucher, J. (2015, March 31). Elon Musk Chose Himself: Here's How [Blog post]. Retrieved from https://medium.com/@jaltucher/elon-musk-chose-himself-here-s-how-ffc4f5f109 $\underline{\mathrm{f}}$.

Aydın, B. (2016). Self-critical friendship: A self-study of a pre-service English language teacher trainer in Turkey. Eğitimde Kuram ve Uygulama (Journal of Theory and Practice in Education), 12(4), 962-978.

Bandura, A. (1994). Self-efficacy. In V. S. Ramachaudran (Ed.), Encyclopedia of human behavior (Vol. 4, pp. 71-81). New York: Academic Press. (Reprinted in H. Friedman [Ed.], Encyclopedia of mental health. San Diego: Academic Press, 1998). Retrieved from https://www.uky.edu/ eushe2/Bandura/BanEncy.html

Brouwers, A., \& Tomic, W. (2000). A longitudinal study of teacher burnout and perceived self-efficacy in classroom management. Teaching and Teacher Education, 16(2), 239253.

Caprara, G. V., Barbaranelli, C., Steca, P., \& Malone, P. S. (2006). Teachers' self-efficacy beliefs as determinants of job satisfaction and students' academic achievement: A study at the school level. Journal of School Psychology, 44(6), 473-490.

Chester, M. D., \& Beaudin, B. Q. (1996). Efficacy beliefs of newly hired teachers in urban schools. American Educational Research Journal, 33(1), 233-257.

Covington, M. V. (2000). Goal theory, motivation, and school achievement: An integrative review. Annual Review of Psychology, 51(1), 171-200. 
AJESI - Anadolu Journal of Educational Sciences International, 2019; 9(2): 852-880

DOI: 10.18039/ajesi.583809

Deci, E. L., \& Ryan, R. M. (1985). The general causality orientations scale: Selfdetermination in personality. Journal of Research in Personality, 19(2), 109-134.

Deci, E. L., \& Ryan, R. M. (2000). The" what" and" why" of goal pursuits: Human needs and the self-determination of behavior. Psychological Inquiry, 11(4), 227-268.

Donohoo, J., Hattie, J., \& Eells, R. (2018). The power of collective efficacy. Educational Leadership, 75(6), 40-44.

İpek, H., Akçay, A., Atay, S. B., Berber, G., Karalik, T., \& Yilmaz, T. S. (2018). The Relationship Between Occupational Stress and Teacher Self-Efficacy: A Study with EFL Instructors. Anadolu Journal of Educational Sciences International, 8(1), 126150.

La Guardia, J. G., Ryan, R. M., Couchman, C. E., \& Deci, E. L. (2000). Within-person variation in security of attachment: a self-determination theory perspective on attachment, need fulfillment, and well-being. Journal of Personality and Social Psychology, 79(3), 367.

Loughran, J. (2007). Researching teacher education practices: Responding to the challenges, demands, and expectations of self-study. Journal of Teacher Education, 58(1), 12-20.

Machin, L., Hindmarch, D., Murray, S., \& Richardson, T. (2015). Understanding Roles and Responsibilities in Education and Training [Blog post]. Retrieved from https://thecriticalblog.wordpress.com/2013/09/11/understanding-roles-andresponsibilities-in-education-and-training/

Mojavezi, A., \& Tamiz, M. P. (2012). The impact of teacher self-efficacy on the students' motivation and achievement. Theory and Practice in Language Studies, 2(3), 483-491.

Ninković, S. R., \& Knežević Florić, O. Č. (2018). Transformational school leadership and teacher self-efficacy as predictors of perceived collective teacher efficacy. Educational Management Administration \& Leadership, 46(1), 49-64. 
AJESI - Anadolu Journal of Educational Sciences International, 2019; 9(2): 852-880

DOI: 10.18039/ajesi.583809

Onafowora, L. L. (2005). Teacher efficacy issues in the practice of novice teachers. Educational Research Quarterly, 28(4), 34-43.

Ozder, H. (2011). Self-efficacy beliefs of novice teachers and their performance in the classroom. Australian Journal of Teacher Education, 36(5), 1-15.

Pinnegar, S., \& Hamilton, M. L. (2009). Self-study of practice as a genre of qualitative research: Theory, methodology, and practice (Vol. 8). Springer Science \& Business Media.

Ryan, R. M., \& Deci, E. L. (2000). Intrinsic and extrinsic motivations: Classic definitions and new directions. Contemporary Educational Psychology, 25(1), 54-67.

Ryan, R. M., \& Deci, E. L. (2000). Self-determination theory and the facilitation of intrinsic motivation, social development, and well-being. American psychologist, 55(1), 68-78.

Samaras, A. P. (2010). Self-study teacher research: Improving your practice through collaborative inquiry. California: Sage.

Schuck, S., \& Russell, T. (2005). Self-study, critical friendship, and the complexities of teacher education. Studying Teacher Education, 1(2), 107-121.

Thompson, G., \& Woodman, K. (2019). Exploring Japanese high school English teachers' foreign language teacher efficacy beliefs. Asia-Pacific Journal of Teacher Education, $47(1), 48-65$.

Tschannen-Moran, M., Hoy, A. W., \& Hoy, W. K. (1998). Teacher efficacy: Its meaning and measure. Review of Educational Research, 68(2), 202-248.

Tschannen-Moran, M., \& Hoy, A. W. (2001). Teacher efficacy: Capturing an elusive construct. Teaching and Teacher Education, 17(7), 783-805.

Tschannen-Moran, M., \& Hoy, A. W. (2007). The differential antecedents of self-efficacy beliefs of novice and experienced teachers. Teaching and Teacher Education, 23(6), 944-956. 
AJESI - Anadolu Journal of Educational Sciences International, 2019; 9(2): 852-880 DOI: 10.18039/ajesi.583809

Ulanoff, L. (2012, April 13). Elon Musk: secrets of a highly effective entrepreneur. Retrieved from https://mashable.com/2012/04/13/elon-musk-secrets-of-effectiveness/

Yılmaz, C. (2011). Teachers' perceptions of self-efficacy, English proficiency, and instructional strategies. Social Behavior and Personality: An international journal, 39(1), 91-100. 